\title{
COST ECONOMICS OF DRIP IRRIGATED WHEAT
}

\author{
D. M. DANGAR, D. K. DWIVEDI \& H. H. MASHRU \\ Department of Soil and Water Engineering, College of Agricultural Engineering \& \\ Technology,Junagadh Agricultural University,Junagadh, Gujarat, India
}

\begin{abstract}
Drip irrigation has been successful in improving water use efficiency and yielding excellent quality of produce in most crops. However, the major constraint faced by the farmers is that of the initial capital investment. Hence, for the farmers to adopt drip irrigation on wheat crop, it becomes necessary to evaluate the cost of the drip irrigation system and come up with a setup that can reduce its cost without affecting the yield, significantly. In this study, drip irrigation has been applied to wheat crop at three lateral spacings of $0.6 \mathrm{~m}, 0.8 \mathrm{~m}$ and $1.0 \mathrm{~m}$ and three irrigation regimes of 0.6 IW/CPE (Irrigation water/cumulative pan evaporation), 0.8 IW/CPE and 1.0 IW/CPE. Cost economics for the three spacing levels and irrigation levels has been evaluated in this study. The fixed cost of drip irrigation was found to be $\square 1,94,632$, $1,52,017$ and $\square 1,26,132$, respectively for lateral spacing of $0.6 \mathrm{~m}, 0.8 \mathrm{~m}$ and $1.0 \mathrm{~m}$. The lowest cost of cultivation in drip irrigation was found as $\square 35643$ /ha at lateral spacing of $1.0 \mathrm{~m}$ and irrigation level of $1.0 \mathrm{IW} / \mathrm{CPE}$ with benefit cost ratio of 1.90. The highest net return under drip irrigation system was found to be $\square 45007 / h a$ under lateral spacing of $0.6 \mathrm{~m}$ and irrigation level of 1.0 IW/CPE. The lowest benefit by cost ratio of 1.19 was obtained under the lateral spacing of $1.0 \mathrm{~m}$ and irrigation level of $0.6 \mathrm{IW/CPE}$.
\end{abstract}

KEYWORDS: Wheat, Drip Irrigation, Irrigation Regimes, Lateral Spacing\& Cost Economics

Received: Jul 08, 2017; Accepted: Jul 25, 2017; Published: Jul 29, 2017; Paper Id.: IJASRAUG201766

\section{INTRODUCTION}

India ranks second in wheat production with average productivity of three tons per hectare in the world. India's share in world wheat area is about $12.5 \%$, and it produces $12 \%$ of total production of wheat in the world.The demand for wheat will increase $60 \%$ in comparison to 2010 in future, with the predicted world population of 9.3 billion by 2050(FAO).

Drip irrigation, apart from increasing water use efficiency also increases the crop productivity and reduces cultivation cost and electrical consumption. Cost reduces due to lesser labor intensive operations like weeding and ploughing. The pumping hours are also less in drip irrigation, which causes reduction in cost of electricity. Though drip irrigation can be suitably applied to wheat, limited studies have been conducted to indicate economic viability. Drip irrigation can save up to $20 \%$ of water compared to surface irrigation in case of wheat crop (Kharrou et al., 2011). Higher profitability is found in drip irrigation due to increases in production and reduction in cultivation cost. A farmer can save about $1260 \mathrm{kwh} / \mathrm{acre}$ of electricity, reduce cost of cultivation and benefit cost ratio of 1.98 (Narayanamoorthy, 2005). Drip irrigation for horticultural crops and orchard crops is viable economically, as these crops are high valued. In intensive field crops, the drip irrigation has higher capital cost and it can be reduced by increasing the spacing of laterals (Pandya \& Rank, 2014). It is important to evaluate the cost economics considering the investment of drip irrigation system and crops. It is advisable to convert the water saving benefits and convert it in monetary terms on the basis of market price. The details of the cost economics including the cost of cultivation, fixed 
cost of drip irrigation system per hectare and total cost of irrigation in wheat per hectare in subsequent sections.

\section{MATERIALS AND METHODS}

\section{Location}

The experiment was conducted at Instructional Farm, Department of Soil and Water Engineering, College of Agricultural Engineering and Technology, Junagadh Agricultural University, Junagadh. It is located at $21.5^{\circ} \mathrm{N}$ latitude and $70.1^{\circ} \mathrm{E}$ longitude with an altitude of 60 meters above mean sea level on the western side foothills of Mount Girnar. The location is situated in South Saurashtra Agro climatic Zone of Gujarat State.

\section{Climate}

The study area is having typically subtropical and semi-arid climate, characterized by fairly cold and dry winter, hot and dry summer and warm and moderately humid during monsoon. Partial failure of monsoon once in three to four years is common in this region. Winter sets in the month of November and continues till the end of February. January is the coldest month of winter. Summer commences in the second fortnight of February and ends in the middle of June. April and May are the hottest months of summer.

\section{Experimental Details}

The irrigation regimes selected in the present investigation include 0.6 IW/CPE, 0.8 IW/CPE and 1.0 IW/CPE. Three lateral spacing was selected based on the wetting pattern of 4 lph emitter discharge in clay soil. The three lateral to lateral spacing includes $0.6 \mathrm{~m}, 0.8 \mathrm{~m}$ and $1.0 \mathrm{~m}$. The emitter to emitter spacing was invariant and kept at $0.6 \mathrm{~m}$ spacing on the $16 \mathrm{~mm}$ lateral. An emitter discharge of $4 \mathrm{lph}$ was kept constant throughout all the treatments. Two parallel lateral lines of $16 \mathrm{~mm}$ having $4 \mathrm{lph}$ emitter discharges with $0.6 \mathrm{~m}$ emitter spacing were confined to form a triangular pattern. In this study, GW 496 variety was selected for experiment. Soil was brought to fine tilt by two ploughing with rotary tiller (rotavator). Stubbles of previous crops were collected and removed from the experiment field. Beds of $2.0 \mathrm{~m} \mathrm{x} 9.0 \mathrm{~m}$ size were prepared before sowing of seeds.

\section{Statistical Design and Experimental Layout}

In the present study, impact of three irrigation regimes and three lateral spacing were analyzed using split plot design. There are 9 treatments existing in the present investigation. Each treatment was replicated thrice. The first factor was irrigation regimes and second factor was lateral spacing. Split plot design was used for analysis.

Table 1: Details of Factors

\begin{tabular}{|l|c|}
\hline \multicolumn{2}{|c|}{ Main Factor: Lateral Spacing } \\
\hline $\mathrm{S}_{1}$ & $0.6 \mathrm{~m}$ \\
\hline $\mathrm{S}_{2}$ & $0.8 \mathrm{~m}$ \\
\hline $\mathrm{S}_{3}$ & $1.0 \mathrm{~m}$ \\
\hline \multicolumn{2}{|c|}{ Sub Factor: Irrigation Regimes } \\
\hline $\mathrm{I}_{1}$ & $0.6 \mathrm{IW} / \mathrm{CPE}$ \\
\hline $\mathrm{I}_{2}$ & $0.8 \mathrm{IW} / \mathrm{CPE}$ \\
\hline $\mathrm{I}_{3}$ & $1.0 \mathrm{IW} / \mathrm{CPE}$ \\
\hline
\end{tabular}

Table 2: Details of Treatment Combination

\begin{tabular}{|c|c|c|c|}
\hline \multicolumn{2}{|c|}{ Treatment } & Irrigation Ratio & Lateral Spacing (M) \\
\hline $\mathrm{T} 1$ & $\mathrm{I}_{1} \mathrm{~S}_{1}$ & $0.6 \mathrm{IW} / \mathrm{CPE}$ & 0.6 \\
\hline
\end{tabular}




\begin{tabular}{|c|c|c|c|}
\hline \multicolumn{3}{|c|}{ Table 2: Contd., } \\
\hline $\mathrm{T} 2$ & $\mathrm{I}_{1} \mathrm{~S}_{2}$ & $0.6 \mathrm{IW} / \mathrm{CPE}$ & 0.8 \\
\hline $\mathrm{T} 3$ & $\mathrm{I}_{1} \mathrm{~S}_{3}$ & $0.6 \mathrm{IW} / \mathrm{CPE}$ & 1.0 \\
\hline $\mathrm{T} 4$ & $\mathrm{I}_{2} \mathrm{~S}_{1}$ & $0.8 \mathrm{IW} / \mathrm{CPE}$ & 0.6 \\
\hline $\mathrm{T} 5$ & $\mathrm{I}_{2} \mathrm{~S}_{2}$ & $0.8 \mathrm{IW} / \mathrm{CPE}$ & 0.8 \\
\hline $\mathrm{T} 6$ & $\mathrm{I}_{2} \mathrm{~S}_{3}$ & $0.8 \mathrm{IW} / \mathrm{CPE}$ & 1.0 \\
\hline $\mathrm{T} 7$ & $\mathrm{I}_{3} \mathrm{~S}_{1}$ & $1.0 \mathrm{IW} / \mathrm{CPE}$ & 0.6 \\
\hline $\mathrm{T} 8$ & $\mathrm{I}_{3} \mathrm{~S}_{2}$ & $1.0 \mathrm{IW} / \mathrm{CPE}$ & 0.8 \\
\hline $\mathrm{T} 9$ & $\mathrm{I}_{3} \mathrm{~S}_{3}$ & $1.0 \mathrm{IW} / \mathrm{CPE}$ & 1.0 \\
\hline
\end{tabular}

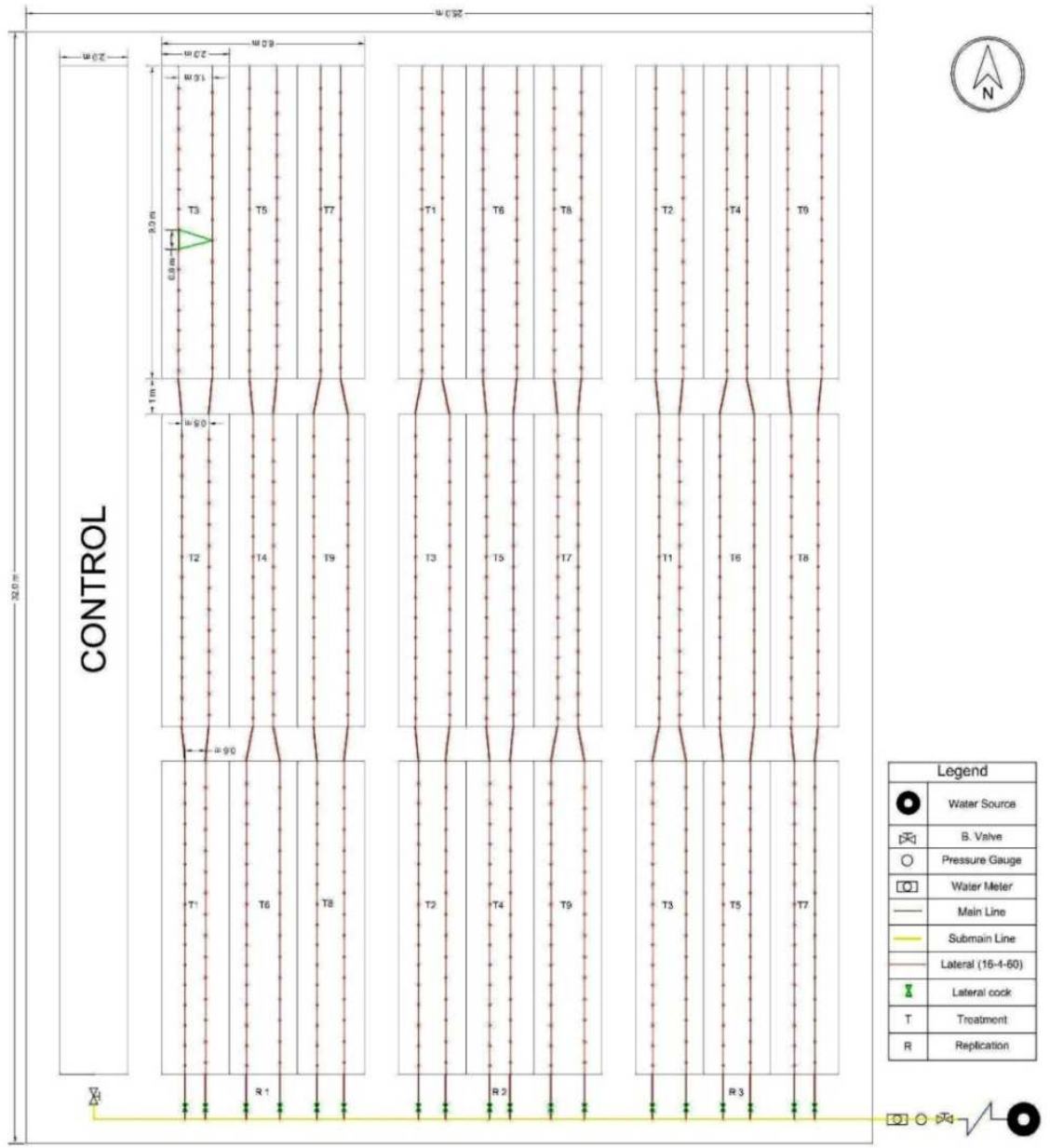

Figure 1: Experimental Layout

\section{Economics}

The economics of wheat cultivation includes the total cost and total income per unit area. The total cost of cultivation was computed using the following expression:

$T C C=C C C+F C I+V C I$

Where,

TCC is the total cost of wheat cultivation ( $\square /$ ha/season) CCC is the common cost of cultivation ( $\square /$ ha/ season) FCI is the fixed cost of irrigation ( $\square / \mathrm{ha} /$ season) VCI is the variable cost of irrigation ( $\square / \mathrm{ha} /$ season) 


\section{Common Cost of Cultivation}

Common cost of cultivation (CCC) includes cost towards the common agronomic practices like ploughing, harrowing, sowing, top dressing, weeding, inter-cultivation, harvesting, plant protection measures and fertilizer application and common inputs like seeds, fertilizer, weedicides, etc.

\section{Fixed Cost ofIrrigation}

The fixed cost of irrigation (FCI), in case of all treatments under drip irrigation includes the cost of pumping unit, drip irrigation system and its installation. While in case of treatments under border irrigation included the cost of pumping unit, making bunds and water conveyance channel. The FCI was calculated as below:

$F C I=S C_{p s}+S C_{i s}+S C_{i d}($ For drip method $)$

$F C I=S C_{p s}+S C_{b c}($ For border method $)$

Where,

$\mathrm{SC}_{\mathrm{ps}}$ is the seasonal cost of pumping system ( $\square / \mathrm{ha} /$ season),

$\mathrm{SC}_{\mathrm{is}}$ is the seasonal cost of irrigation system ( $\square / \mathrm{ha} /$ season),

$\mathrm{SC}_{\mathrm{id}}$ is the seasonal cost of installation of drip system ( $\square / \mathrm{ha} /$ season) and

$\mathrm{SC}_{\mathrm{bc}}$ is the seasonal cost of making bunds and channels ( $\square / \mathrm{ha} /$ season)

The seasonal cost of pumping system was computed using the following expression:

$$
S C_{p s}=\frac{P V P S \times i \times(1+i)^{m}}{(A \times s)\left[(1+i)^{m}-1\right]}
$$

Where

PVPS is the present value of the pumping unit ( $\square$ )

$\mathrm{m}$ is the life of the pumping system, taken as 15 years

$\mathrm{i}$ is the prevailing rate of interest (fraction), taken as 0.10

A is the total area commanded by the pumping unit in a season (ha) and

$\mathrm{s}$ is the number of season per year to which the pumping system can be used

PVPS included the purchasing price of the pump, electric motor, suction and delivery pipes, all fittings, accessories, and cost of well construction.

The seasonal cost of drip irrigation system was computed using the following expression

$$
S C_{i s}=\frac{P V I S \times i \times(1+i)^{n}}{s\left[(1+i)^{n}-1\right]}
$$

Where

PVIS is the present value of the irrigation system ( $\square / h a)$, 
$\mathrm{i}$ is the interest rate (fraction), taken as 0.10

$\mathrm{n}$ is the life of the irrigation system, taken as 10 years

$\mathrm{s}$ is the number of season for which the irrigation system be used.

The PVIS included the purchase cost of all required drip irrigation systems' items. It was estimated considering the material quantity for 1 hectare square field under drip irrigation system. The fixed cost of drip irrigation system was calculated considering the 10 years life of system and $10 \%$ rate of interest. The number of season (s) was taken as 2 seasons. The seasonal cost of irrigation system $\left(\mathrm{SC}_{\mathrm{is}}\right)$ included $\mathrm{PVC}$ main line, PVC sub-main line, PVC valves, grommet, take off, pressure gauge, lateral, emitters, filter etc. The $\mathrm{SC}_{\mathrm{is}}$ was taken as zero for the border irrigation. The $\mathrm{SC}_{\mathrm{id}}$ and $\mathrm{SC}_{\mathrm{bc}}$ is taken as $1000 \square$ and $4000 \square$ per ha per season, respectively.

\section{Variable Cost of Irrigation}

The variable cost of irrigation (VCI) included operational cost towards the labor and electricity for pumping, conveyance and irrigation applications and maintenance charges. The pressure head required for operating the drip irrigation system were also taken into account, while calculating the electricity energy inputs. The cost of applying the water per hour under border and drip irrigation was computed using the discharge capacity of pumps, electricity charges and cost of labor for irrigation applications. The variable cost of irrigation was computed using the cost of unit depth of water and total seasonal depth of irrigation under the respective treatment.

\section{Gross Income}

The gross income in terms of $\square$ per hectare was calculated from the wheat grain and straw yield at the prevailing market price. ( $\square 17.50$ per $\mathrm{kg}$ for grain yield and $\square 1.50$ per $\mathrm{kg}$ for straw)

\section{Net Income}

The net income was worked out by deducting the total cost of the cultivation (TCC) from the gross income per hectare for each treatment.

\section{Benefit Cost Ratio}

The benefit cost ratio of wheat cultivation was worked out for each treatment by dividing the gross income with total cost of cultivation.

\section{RESULTS AND DISCUSSIONS}

The results of common cost of cultivation, fixed cost of irrigation, total cost of cultivation, gross return, net return and benefit cost ration has been given this section and discussed.

\section{Common Cost of Cultivation}

The common cost of cultivation of wheat crop was estimated considering the materials and labor cost incurred in common agronomic practices like ploughing, harrowing, sowing, top dressing, weeding, inter-cultivation, harvesting, plant protection measures and fertilizer application and common inputs like seeds, fertilizer, weedicides, etc. and it is given in Table 3. 
Table 3: Common Cost of Cultivation

\begin{tabular}{|l|l|c|}
\hline Sr. No. & \multicolumn{1}{|c|}{ Particulars } & Cost, $\square / \mathrm{Ha}$ \\
\hline 1 & Land preparation & 6500.00 \\
\hline 2 & Seed Rate (125 kg/ha @ 25 $\square / \mathrm{kg}$ ) & 3125.00 \\
\hline 3 & Plant Protection (1 times @ 635 $\square /$ time) & 635.00 \\
\hline 4 & Total bullock power requirement (Pair days) & 1500.00 \\
\hline 5 & $\begin{array}{l}\text { Total human labor requirement } \\
\text { (16 man days @ 150 } \square / \text { mandays) }\end{array}$ & 2400.00 \\
\hline 6 & Cost of fertilizer (120:60:60::N:P:K kg/ha) & 4450.00 \\
\hline 7 & Harvesting of crop & 2500.00 \\
\hline \multicolumn{2}{|l|}{ Common Cost of Cultivation } & $\mathbf{2 1 1 1 0 . 0 0}$ \\
\hline
\end{tabular}

\section{Fixed Cost of Irrigation}

The cost and quantity of drip irrigation for different treatments was calculated as given in Table 4. It was estimated according to material quantity required for designed layout of one hectare square field under different lateral drip irrigation system. The cost of trench digging/filling for main/sub main was also considered on basis of local rate. The fix cost of drip irrigation system was calculated considering the 10 years life of system serving for $10 \%$ rate of interest. Cost of system varies with the lateral spacing, because of varying length of lateral requirement. The highest cost of irrigation system was found in $0.6 \mathrm{~m}$ lateral spacing. Table 5 shows the cost of drip irrigation at different spacing of lateral.

Table 4: Fixed Cost of Irrigation

\begin{tabular}{|c|c|c|c|c|c|c|c|}
\hline \multirow{2}{*}{ No. } & \multirow{2}{*}{ Name of Items/Components } & \multirow{2}{*}{ Size } & \multirow{2}{*}{ Unit } & \multirow{2}{*}{$\begin{array}{l}\text { Rate Per } \\
\text { Unit }(\square)\end{array}$} & \multicolumn{3}{|c|}{ Lateral Spacing } \\
\hline & & & & & $0.6 \mathrm{M}$ & $0.8 \mathrm{M}$ & $1.0 \mathrm{M}$ \\
\hline 1 & Screen filter - $2.5^{\prime \prime}$ & $30 \mathrm{~m}^{3} / \mathrm{h}$ & Nos. & $2,334.58$ & 1 & 1 & 1 \\
\hline 2 & Header assembly & $2.5^{\prime \prime}$ & Nos. & $2,694.51$ & 1 & 1 & 1 \\
\hline 3 & Venturi injector & $2 "$ & Nos. & $3,678.68$ & 1 & 1 & 1 \\
\hline 4 & PP ball valve & $2 "$ & Nos. & 714.31 & 1 & 1 & 1 \\
\hline 5 & Butterfly valve & $2.5^{\prime \prime}$ & Nos. & 896 & 1 & 1 & 1 \\
\hline 6 & Pressure gauge & $2 "$ & Nos. & 196 & 2 & 2 & 2 \\
\hline 7 & Air release valve & $1 "$ & Nos. & 33.6 & 1 & 1 & 1 \\
\hline 8 & PVC Pipe $-4 \mathrm{~kg} / \mathrm{cm}^{2}$ & $75 \mathrm{~mm}$ & $\mathrm{~m}$ & 58.41 & 70 & 70 & 70 \\
\hline 9 & HDPE Pipe $-4 \mathrm{~kg} / \mathrm{cm}^{2}$ & $63 \mathrm{~mm}$ & $6 \mathrm{~m}$ & 496.85 & 17 & 17 & 17 \\
\hline 10 & PP ball valve & $63 \mathrm{~mm}$ & Nos. & 674.02 & 5 & 4 & 3 \\
\hline 11 & Plain lateral & $16 \mathrm{~mm}$ & $\mathrm{~m}$ & 6.9 & 125 & 100 & 70 \\
\hline 12 & Emitting pipe & $16-4-60$ & $\mathrm{~m}$ & 9.88 & 16666 & 12500 & 10000 \\
\hline 13 & Rubber grommet & $16 \mathrm{~mm}$ & Nos. & 1.77 & 350 & 250 & 200 \\
\hline 14 & Start connector & $16 \mathrm{~mm}$ & Nos. & 1.48 & 350 & 250 & 200 \\
\hline 15 & End cap & $16 \mathrm{~mm}$ & Nos. & 1.36 & 350 & 250 & 200 \\
\hline 16 & Jointer & $16 \mathrm{~mm}$ & Nos. & 1.48 & 350 & 250 & 200 \\
\hline \multicolumn{5}{|c|}{ Total } & $\mathbf{1 , 9 4 , 6 3 2}$ & $\square \mathbf{1 , 5 2 , 0 1 7}$ & $\square \mathbf{1 , 2 6 , 1 3 2}$ \\
\hline
\end{tabular}

Table5: Cost of Drip Irrigation System

\begin{tabular}{|c|c|c|}
\hline Sr. No. & Lateral Spacing, $\mathbf{M}$ & Fixed Cost, $\square /$ Ha \\
\hline 1 & 0.6 & $1,94,632$ \\
\hline 2 & 0.8 & $1,52,017$ \\
\hline 3 & 1.0 & $1,26,132$ \\
\hline
\end{tabular}

\section{Total Cost of Cultivation}

The total cost of cultivation of wheat crop was estimated as summation of the fix cost and variable cost of one 
season and it is presented in Table 6, for various lateral spacing and irrigation regimes. Grain yield and straw yield have also been calculated and shown in Table 6. The yield will vary based on interaction effect of irrigation regimes and lateral spacing. The highest and lowest cost of cultivation was found to be $\square 40104$ /ha in treatment $\mathrm{T}_{1}$ and $\square 35386 / \mathrm{ha}$ in control, respectively.

Table6: Cost Economics of Wheat Cultivation

\begin{tabular}{|l|l|l|l|l|l|l|l|l|}
\hline Treatments & $\begin{array}{c}\text { Grain } \\
\text { Yield }\end{array}$ & $\begin{array}{c}\text { Straw } \\
\text { Yield }\end{array}$ & $\begin{array}{c}\text { Variable } \\
\text { Cost }(\square / H a)\end{array}$ & $\begin{array}{c}\text { Fixed } \\
\text { Cost }(\square / H a)\end{array}$ & $\begin{array}{c}\text { TCC } \\
(\square / H a)\end{array}$ & $\begin{array}{c}\text { Gross } \\
\text { Income } \\
(\square / H a)\end{array}$ & $\begin{array}{c}\text { Net } \\
\text { Return } \\
(\square / H a)\end{array}$ & $\begin{array}{c}\text { B:C } \\
\text { Ratio }\end{array}$ \\
\hline $\mathrm{T}_{1}$ & 3548 & 5467 & 21110 & 18994 & 40104 & 70291 & 30187 & 1.75 \\
\hline $\mathrm{T}_{2}$ & 3174 & 4919 & 21110 & 16466 & 37576 & 62924 & 25348 & 1.67 \\
\hline $\mathrm{T}_{3}$ & 2169 & 3429 & 21110 & 15199 & 36309 & 43101 & 6792 & 1.19 \\
\hline $\mathrm{T}_{4}$ & 3903 & 5779 & 21110 & 18634 & 39744 & 76971 & 37227 & 1.94 \\
\hline $\mathrm{T}_{5}$ & 3733 & 5356 & 21110 & 16086 & 37196 & 73362 & 36166 & 1.97 \\
\hline $\mathrm{T}_{6}$ & 2975 & 4411 & 21110 & 14771 & 35881 & 58679 & 22798 & 1.64 \\
\hline $\mathrm{T}_{7}$ & 4298 & 6249 & 21110 & 18472 & 39582 & 84589 & 45007 & 2.14 \\
\hline $\mathrm{T}_{8}$ & 3989 & 5786 & 21110 & 15890 & 37000 & 78487 & 41487 & 2.12 \\
\hline $\mathrm{T}_{9}$ & 3449 & 4996 & 21110 & 14533 & 35643 & 67852 & 32209 & 1.90 \\
\hline Control & 3374 & 5383 & 22340 & 13002 & 35306 & 67119 & 31813 & 1.86 \\
\hline
\end{tabular}

\section{Gross Return}

Gross return was estimated for each treatment, considering the prevailing selling price of 17.50 per kg for grain yield and 1.50 per $\mathrm{kg}$ for straw yield. The highest and lowest gross return under drip irrigation system was found as $\square$ 84589/ha and $\square$ 43101/ha respectively, under treatment $T_{7}$ and $T_{3}$ respectively as shown in Table 6.

\section{Net Return}

The net return was calculated as the difference of gross revenue generated from grain yield and straw yield to the total cost of cultivation of the wheat crop. The highest and lowest net return under drip irrigation system was found as $\square$ 45007/ha and $\square$ 6792/ha respectively, under treatment $T_{7}$ and $T_{3}$ respectively, as shown in Table 6.

\section{Benefit Cost Ratio (B:C)}

The benefit cost ratio of wheat crop was estimated as ratio of gross income to total cost of cultivation. The highest and lowest benefit cost ratio under drip irrigation system was found as 2.14 and 1.19 under irrigation treatment $\mathrm{T}_{7}$ and $\mathrm{T}_{3}$ respectively, as shown in Table 6.

\section{CONCLUSIONS}

- Increase in lateral spacing from $0.6 \mathrm{~m}$ to $1.0 \mathrm{~m}$, the yield and yield attributes of wheat crop reduced for all irrigation regimes. So, $0.6 \mathrm{~m}$ lateral spacing found is better than $0.8 \mathrm{~m}$ and $1.0 \mathrm{~m}$ lateral spacing.

- Highest net return of $\square 45007$ /ha was found with 1.0 IW/CPE and $0.6 \mathrm{~m}$ lateral spacing, and lowest net return of $\square 6792$ /ha was found with 1.0 IW/CPE and $1.0 \mathrm{~m}$ lateral spacing.

- Highest benefit to cost ratio (2.14) was found with treatment $1.0 \mathrm{IW} / \mathrm{CPE}$ with $0.6 \mathrm{~m}$ lateral spacing, while the lowest benefit to cost ratio (1.19) was found at $0.6 \mathrm{IW} / \mathrm{CPE}$ and $1.0 \mathrm{~m}$ lateral spacing.

- Considering the performance of drip irrigation system at $0.6 \mathrm{~m}$ lateral spacing and 1.0 IW/CPE irrigation level, which gave higher grain yield, straw yield, yield attributes and net return, this combination may be adopted for 
wheat cultivation under drip irrigation for increasing the farmers' income.

\section{REFERENCES}

1. FAO Water 2013: Status of Irrigated crops in different countries available athttp://www.fao.org/nr/water/aquastat/countries_regions/IND/IND-CC_eng.pdf accessed at 19th October 2015.

2. Kharrou, M. H., Er-Raki, S., Chehbouni, A., Duchemin, B., Simonneaux, V., LePage, M., andJarlan, L. (2011). Water use efficiency and yield of winter wheat under different irrigation regimes in a semi-arid region. Agricultural Sciences in China, 2(03), 273-282.

3. Narayanamoorthy, A. (2004). Drip irrigation in India: can it solve water scarcity? Water Policy, 6(2), 117-130.

4. Pandya, P. A. and Rank, H. D. (2015). Techno economic feasibility of high discharge drip irrigation and mulch for summer sesame. Agricultural Engineering Today. 39(1): 1-7.

5. Rahman GA. (2009). Water use efficiency of wheat under drip irrigation-systems. American-Eurasian J Agric \& Environ Sci. 5(5):664-70.

6. Sharma, G. R.; Prajapati, G. V.; Masharu, H. H. and Satasiya, R. M. (2007). Guidelines and standardization of drip irrigation in different crops. Center of excellence on soil and water management. Junagadh Agricultural University, Junagadh. 1-3. 